\title{
The Effectiveness of Technical Guidance for Entrepreneurs in Small and Medium Enterprises in Facing Halal Certification
}

\author{
Siska $^{1 *}$, Hanifah Rahmi ${ }^{2}$, Almawati Situmorang ${ }^{3}$ \\ ${ }^{1,2,3}$ Faculty of Pharmacy and Science, Universitas Muhammadiyah Prof. Dr. HAMKA, East Jakarta 13460, \\ Indonesia

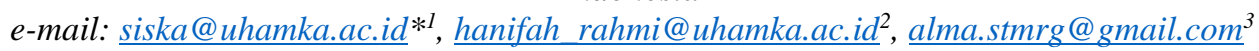

*Correspondent Author

\begin{abstract}
Indonesia is the largest Muslim population country in the world, so the market demand for halal products is enormous. However, in fact, there are not many business actors who submit and have halal certificates, especially in small and medium enterprises. This problem can be due to lack of information and sufficient understanding to apply for a halal certificate. The aim of the research is to give technical guidance for preparing halal certification process. The manual method is used to provide training on the halal guarantee system for the preparation of the halal assurance system (HAS). The workshop began with a pre-test and then the presentation of halal assurance system material, the guidance on how to prepare and discussion. All the activities were done by online (WhatsApp group and zoom meeting). The training ended with the post-test to assess the improvement of knowledge of the. To analyze the difference, we used a paired T-test statistical method. The result of this research shows an increasing understanding of participants $(p<0,05)$ through the comparison between before and after training. These activities conclude that the practice of technical guidance for facing halal certification is beneficial for small and medium enterprises in improving knowledge and capability of the halal certification process.
\end{abstract}

Keywords: halal certification, small and medium enterprises, technical guidance

\section{Introduction}

Halal product is essential for the Muslim population in the world. As Muslims, we are required to consume halal food/drinks. As mentioned in Quran chapter 2, verse 168:

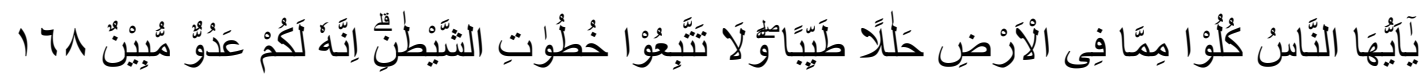

$O$, ye people! Eat of what is on earth, Lawful and good; and do not follow the footsteps of the evil one, for he is to you an avowed enemy (Quran chapter 2, verse 168).

Indonesia, as the largest Muslim country, is obliged to meet the needs of halal food for citizens who are Muslim. Along with this, the government has issued Law Number 33 of 2014 concerning Halal Product Guarantee (Goverment of the Republic of Indonesia, 2014). The existence of this law requires all industrial players both in the field of processed food/beverages to have halal certificates. Halal certificate is the requirement to get permission to put halal label on product packaging from the authorized government agency. Halal logo is essential to put on the products label, and we can be noticed whether the products are halal or not. It will help to protect Muslim consumer from non-halal products.

But in reality, there are not many business actors who submit and have halal certificates, especially in small and medium enterprises. This problem can be due to lack of information and sufficient understanding to apply for halal certification. One aspect that is not widely understood is how to draw up a halal guarantee system document. Halal Assurance System (HAS) is an integrated management system that regulates materials, production processes, products, human resources, and procedures to maintain the continuity of the halal production process (HAS 23000) (The Assessment Institute For Food, Drugs, and Cosmetics The Indonesian Council of Ulama (LPPOM MUI), 2012).

The Faculty of Pharmacy and Science is one of the faculties at UHAMKA who initiated the birth of the UHAMKA Halal Study Center (PKHU). Those faculty has several certified halal auditors and halal supervisors. Based on the expertise in the halal sector, this service activity could help small 
and medium enterprises to raise their knowledge of the halal certification process, especially preparing the HAS documents. There are more than 30 small and medium enterprises around UHAMKA which are not proposed halal certification yet.

The target of this activity is businesses in the field of food/beverage processing of Small and Medium Enterprises at the Duren Sawit area of East Jakarta. This area is in the same location as UHAMKA, and some of them have a food counter at the canteen. This is the reason why we choose this area. The participation of these business actors is expected to be able to maintain and guarantee the halal of the products (food/drink) they process so that consumers become more confident and calm about the food they consume by Islamic sharia.

\section{Materials and Methods}

The organizer of this activity is the teaching staffs at the UHAMKA Jakarta Faculty of Pharmacy and Science. They are also internal resource members. The topic of the training comprises a material that includes halal and haram restrictions according to the Qur'an and Al-Hadith, the importance of halal certificates for business actors, as well as the halal guarantee system criteria. The facilitator guided the group of the participant based on their product categories. Twenty participants have attended the workshop. The participants who would attended the meeting should register two weeks before the date. There were more than 20 who have registered, but some of them have resigned because of the pandemic we change the method from offline to an online platform. Not all participant familiar with the online learning platform. All the activities were done by online on March 31 until April 3, 2020, via WhatsApp group and Zoom meeting.

The first day, began with pre-test and then the presentation of halal assurance system material, dialogue/ question and answer, discussion about the material provided, as well as business group mapping. The contents provided were including halal and haram restrictions according to the Qur'an and Al-Hadith, the importance of halal certificates, halal guarantee system criteria, and steps in registering halal certificates.

The second day, the activity was carried out by providing technical guidance to prepare the HAS document. The action began with material presentation by speakers who followed direct supervision in arranging Halal Assurance System (HAS) document model based on HAS 23000. Participants were divided into four groups according to their different product types. One facilitator will accompany each group.

At the third day, participants were guided to practice the technical preparation of the HAS documents following their respective business fields. The facilitator assessed and gave input for the assignment. The training ended up with a post-test. The data pre and post-test analyzed by paired t-test using SPSS 16 to compare increases in knowledge of the participant before and after the training.

\section{Results and Discussion}

Islam as religion and also a way of life not only regulates aspects of worship and ritual, even further it controls the mindset, actions even to the diet whatever is used and consumed by a human (Farid \& Basri, 2020). Muslims are taught to eat clean and safe food. Islam is very concerned about the sources and cleanliness of food, how to cook, how to serve, how to eat, and how to dispose of leftovers (Zulaekah, 2005). The command to consume halal food is clearly defined in the two sources of reference for Muslims, namely Quran and Al-Hadith (Nazihah \& Arifin, 2020).

Law No. 33 of 2014 concerning Halal Product Guarantee was effective on October 17, 2019. It regulates the obligation to carry out halal certification for business actors. Article 4 from the law states that all products that enter circulate and trade within the territory of Indonesia must be halal-certified. The products that must be certified halal are listed in the statute and government regulations. Products are goods and services related to food, beverages, medicines, cosmetics, chemical products, and biological products. Genetic engineering products, as well as used goods that are used or utilized by the community (Government of the Republic of Indonesia, 2019). The implementation of halal certification as of October 17, 2019, is carried out by the government through the Halal Product Guarantee Agency (BPJPH) (The Assessment Institute For Food, Drugs, and Cosmetics The Indonesian Council of Ulama (LPPOM MUI), 2018).

Halal is an overgrowing market needs. The Muslim population in the world is $28.68 \%$ of the world population or 2.18 billion. In comparison, in Indonesia, it reaches 207 million or $87.2 \%$ of the 
total population in Indonesia (Ministry of Communication and Informatics, Republic of Indonesia, 2019). That is why small and medium enterprises need to get halal certificates to compete with other industries. Business actors who want to obtain MUI halal certificates, both processing industries (food, medicine, cosmetics), slaughterhouse, and restaurants/ catering/ kitchen, must register for halal certification and meet the halal certification requirements. They are some step that must be passed by the company. The following steps are to fulfil the policies and procedures of halal certification and fulfil and implementation of the eleven criteria of Halal Assurance System. The implementation of HAS including preparing HAS documents, registering halal certification, monitoring pre-audit and payment of certification contracts, conducting audits, conducting post-audit monitoring, and obtaining halal certificates (The Assessment Institute For Food, Drugs, and Cosmetics The Indonesian Council of Ulama (LPPOM MUI), 2018). However, many small and medium enterprises do not understand how to prepare halal guarantee system documents on each of their products. This halal guarantee system is a requirement to guarantee the halal status of the product during the validity of the MUI halal certificate. Halal certificates for the food and beverage industry are essential because halal certificates provide halal guarantees for product that will ultimately provide peace of mind for the community. According to the previous research showed halal certification, halal awareness, food ingredients affect purchase intention by $28.8 \%$ (Budiman, 2019).

In the discussion session participants also asked questions related to the product. For example, whether fermented products such as black sticky tape, can be certified halal or not. All products that did not contain haram and najis ingredients can be carried out the halal certification process. Black glutinous tape products made with the fermentation process with the addition of yeast can be certified halal as long as they did not contain haram and najis ingredients and are produced in facilities that are not contaminated with haram and najis ingredients. The commonly debated question is what about the alcohol content in the tape product. The fermentation tape will produce alcohol with different levels depending on the length of time of fermentation. The longer the fermentation, the higher the alcohol content can even reach $7.581 \%$ if fermented for 120 hours (Febrianti et al., 2018). Then what about the law? According to MUI Fatwa No.4 of 2003: Tape and air tape are not included khamr, except when intoxicating. Liquor made from tapered water tape with an ethanol content of at least $1 \%$ including the khamr category. Based on the preceding, fermented tape products can be certified as long as the juice is not separated from the tape.

Evaluations conducted for the participants of this activity are pre-test and post-test. Statistical test results (paired sample) showed that there was an increase in understanding about halal and halal certification processes $(\mathrm{p}<0.05)$ (Figure 1). The evaluation graph illustrates the difference in scores obtained before and after the workshop and training. In the pre-test, the participants mostly didn't know about what it's halal criteria, how to prepare the documents for applying the halal registration, etc. After the training, more than $50 \%$ of participants could understand the point. It was clear that the improvement occurred; more than one of the participants got a score of 100, which meant that they could answer all questions correctly.

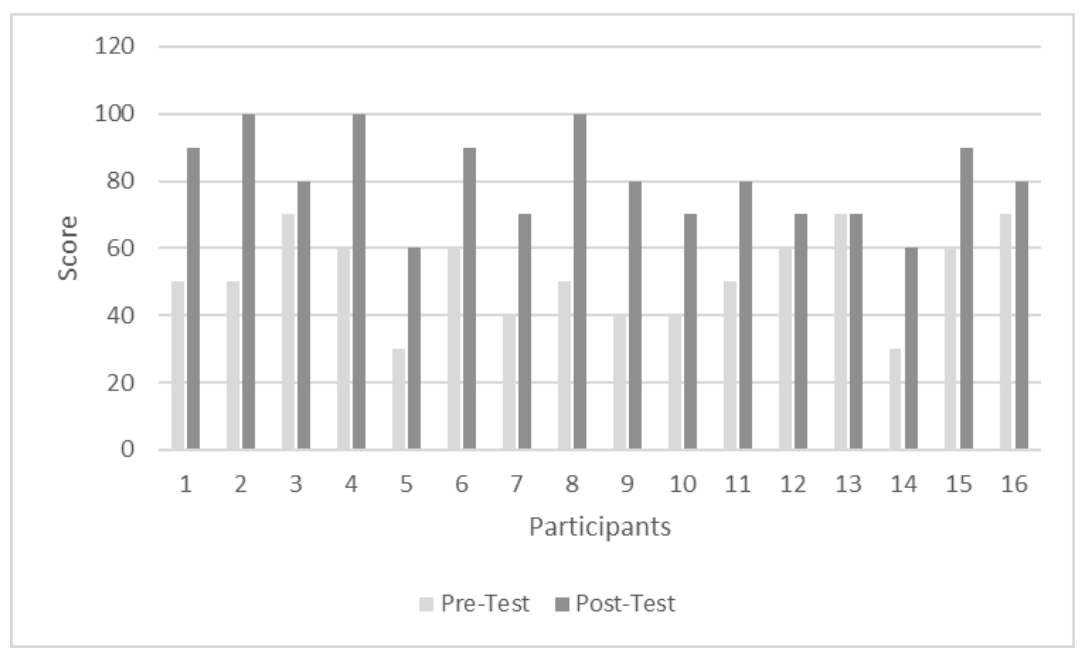

Figure 1. Evaluation Results of Training Participants 
This activity is expected to produce outcomes in the form of increased awareness and skills of business operators, especially at Duren Sawit. They have sustainable guidelines that guarantee the halal of the product by implementing Halal Guarantee System (HAS). Besides, this activity can increase the confidence of the small and medium enterprises owner, so they do not hesitate to register their products for halal certification.

\section{Conclusion}

The presence of law regarding the guarantee of halal products encourages food, drug and cosmetic industry stakeholders to obtain halal certificates. Nevertheless, regulation and technical information on the arrangement and preparation of Halal Certificates are still limited. Therefore, it is necessary to have training and socialization related to halal certificate processing. The training of the technical guidance of the halal certification process has a positive impact on the participants. This impact is proven from the results of the evaluation. The method applied in this activity is following the problems faced by small and medium enterprises, especially in the Duren Sawit. Hopefully, after attending this workshop, they can implement it to their daily activity and do not hesitate to register their products for halal certification. This research will be a continuous program to other regions around Jakarta.

\section{Acknowledgements}

Special thanks to Research Institutions and Community Service Universitas Muhammadiyah Prof. Dr. HAMKA who have supported funding in this activity through the Contract Agreement Letter No. 0103/H.04.02/2020, January 28, 2020.

\section{References}

Budiman, R. (2019). Factors Influencing Purchase Intention of Halal Products in Pontianak City. Indonesian Journal of Halal Research, 1(2), 46-48. https://doi.org/10.5575/ijhar.v1i2.4440.

Farid, M., \& Basri, H. (2020). The Effects of Haram Food on Human Emotional and Spiritual Intelligence Levels. Indonesian Journal of Halal Research, 2(1), 21-26. https://doi.org/10.15575/ijhar.v2i1.7711.

Febrianti, F., Abdurahman, M., \& Surahman, M. (2018). Tinjauan Fatwa MUI Nomor 4 Tahun 2003 tentang Standarisasi Halal Terhadap Makanan yang Dibuat Dari Ketan (Studi Kasus Desa Senang Kecamatan Bayongbong Garut). Prosiding Keuangan Dan Perbankan Syariah, 4(1), $170-175$.

Kementerian Komunikasi dan Informasi Republik Indonesia. (2019). Portal Informasi Indonesia. Retrieved from www.indonesia.go.id/profil/agama\%0A.

Lembaga Pengkajian Pangan Obat-obatan dan Kosmetika Majelis Ulama Indonesia. (2012). Persyaratan Sertifikasi Halal HAS 23000. Bogor: LPPOM MUI.

Lembaga Pengkajian Pangan Obat-obatan dan Kosmetika Majelis Ulama Indonesia. (2018). Prosedur Sertifikasi Halal MUI. Retrieved from www.halalmui.org/mui14/main/page/prosedur-sertifikasihalal-mui\%0A.

Nazihah, A., \& Arifin, B. S. (2020). The Impact of Food on Muslims Spiritual Development. Indonesian Journal of Halal Research, 2(1), 27-32. https://doi.org/10.5575/ijhar.v2i1.7802.

Pemerintah Republik Indonesia. Undang-Undang Jaminan Produk Halal. , Pub. L. No. 33 (2014).

Pemerintah Republik Indonesia. Peraturan Pelaksanaan Undang-Undang Nomor 33 Tahun 2014 Tentang Jaminan Produk Halal. , Pub. L. No. 31 (2019).

Zulaekah. (2005). Halal dan Haram Makanan dalam Islam. Jurnal Suhuf, 17(1).

(C) 2020 by the authors. Submitted for possible open access publication under the terms and conditions of the Creative Commons Attribution (CC BY SA) license (https://creativecommons.org/licenses/by-sa/4.0/). 